\title{
Wave climate and coastal processes in the Osmussaar-Neugrund region, Baltic Sea
}

\author{
Ü. Suursaar ${ }^{1}$, R. Szava-Kovats ${ }^{2} \&$ H. Tõnisson ${ }^{3}$ \\ ${ }^{1}$ Estonian Marine Institute, University of Tartu, Estonia \\ ${ }^{2}$ Institute of Ecology and Earth Sciences, University of Tartu, Estonia \\ ${ }^{3}$ Institute of Ecology, Tallinn University, Estonia
}

\begin{abstract}
The aim of the paper is to investigate hydrodynamic conditions in the Neugrund Bank area from ADCP measurements in 2009-2010, to present a local long-term wave hindcast and to study coastal formations around the Neugrund. Coastal geomorphic surveys have been carried out since 2004 and analysis has been performed of aerial photographs and old charts dating back to 1900. Both the in situ measurements of waves and currents, as well as the semi-empirical wave hindcast are focused on the area known as the Neugrund submarine impact structure, a 535 million-years-old meteorite crater. This crater is located in the Gulf of Finland, about $10 \mathrm{~km}$ from the shore of Estonia. The depth above the central plateau of the structure is $1-15 \mathrm{~m}$, whereas the adjacent sea depth is 20 $40 \mathrm{~m}$ shoreward and about $60 \mathrm{~m}$ to the north. Limestone scarp and accumulative pebble-shingle shores dominate Osmussaar Island and Pakri Peninsula and are separated by the sandy beaches of Nõva and Keibu Bays. The Osmussaar scarp is slowly retreating on the north-western and northern side of the island, whereas the coastline is migrating seaward in the south as owing to formation of accumulative spits. The most rapid changes have occurred either during exceptionally strong single storms or in periods of increased cyclonic and wave activity, the last high phase of which occurred in 1980s-1990s.
\end{abstract}

Keywords: wave hindcast, coastal dynamics, impact crater, climate change.

\section{Introduction}

The Neugrund Bank is an intriguing locale at the entrance of the Gulf of Finland. In the 1990s, the nearly circular-shape shoal was recognised as a meteorite 
impact structure $[1,2]$. Since this discovery, the area has drawn much attention from geophysicists, marine archaeologists and biologists. The shoal has been proposed as a possible location for a wind farm. In order to study long-term variations in coastal processes and to incorporate the almost tideless Estonian coastal sea with wave hindcasts, the shoal was chosen as the third location after Vilsandi-Harilaid [3] and Letipea-Kunda [4] regions (Fig. 1).

The coasts encircling the shoals are very diverse, ranging from the limestone cliffs of the Pakri Islands and Peninsula to the "singing sands" of Keibu and Nõva beaches (Fig. 2). Despite having seen far less study than others, e.g. the coasts of West Estonia, these coasts are nonetheless experiencing increasing pressure, both climate change-related, as well as anthropogenic. For example, the Pakri Islands have been proposed as a possible location for the first Estonian nuclear power plant.

The aim of this study is to investigate hydrodynamic conditions in the Neugrund Bank area on the basis of wave and current measurements during five months in winter 2009/10, to present a local wave hindcast for the period 19662009 and to study coastal formations and their development with respect to temporal variations in climatological and hydrodynamical forcing conditions.

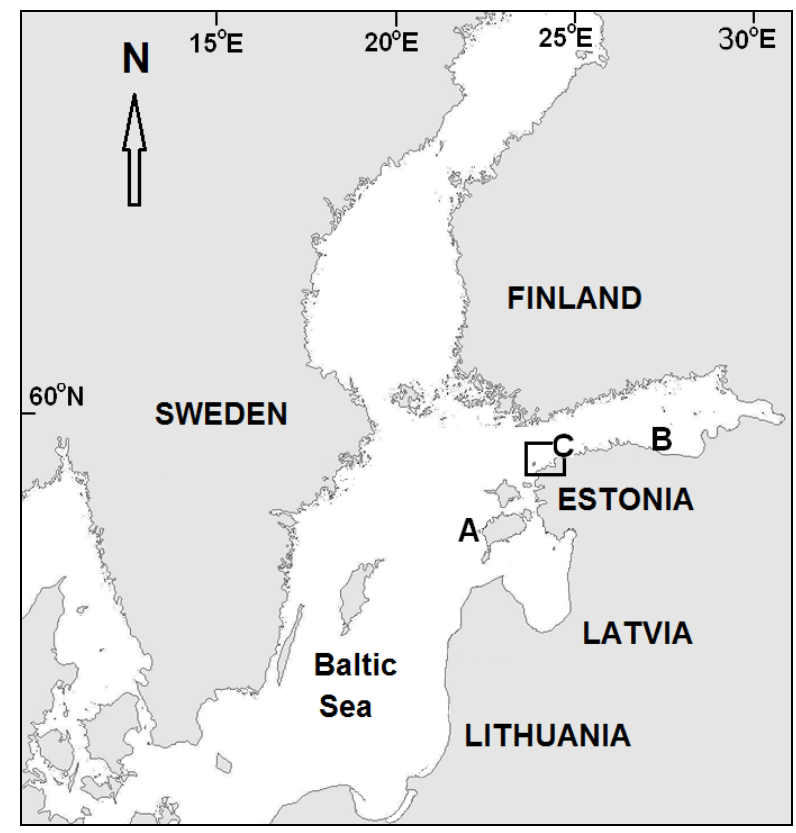

Figure 1: Map of the study area. The rectangle shows the Neugrund study area (Fig. 2). The locations of meteorological stations and respective wave hindcasts: Harilaid-Vilsandi (A), Letipea-Kunda (B), and Pakri Peninsula (C). 


\section{Study area}

\subsection{The Neugrund impact structure}

Both the in situ measurements of waves and currents, as well as the semiempirical wave hindcast are focused on the area known as Neugrund submarine impact structure, a ca. 535 million-year-old meteorite crater with a rim-to-rim diameter of 7-8 km [1]. The buried but partially re-exposed (during Neogene erosion) structure is located in the Gulf of Finland, about $10 \mathrm{~km}$ off the Estonian coast. The water depth at the central plateau is $1-15 \mathrm{~m}$, whereas the adjacent sea depth is $20-40 \mathrm{~m}$ shoreward and $60-70 \mathrm{~m}$ in the circular canyon-like depression to the north (Fig. 2). The great number of shipwrecks lying on the seabed on and around the shoal testifies to the unusually rugged bottom topography in this region. More than a hundred isolated erratic boulders consisting of brecciated Precambrium metamorphic rock are situated on the seabed and coasts around the structure. Mineralogic and microscope evidence of the fine-grained glassy gneiss breccias indicate shock metamorphism. In the late 1990s, this evidence together with detailed geophysical mapping, seismoacoustic and magnetic profiling - served to demonstrate that the Neugrund Bank is a meteorite crater with an initial structural altitude of about $500 \mathrm{~m}$ [2]. The current structural elements consist of a rimwall attaining $50 \mathrm{~m}$, the crater proper, ejecta, and a 20 $\mathrm{km}$ outer ring fault (Fig. 2) [1, 2].

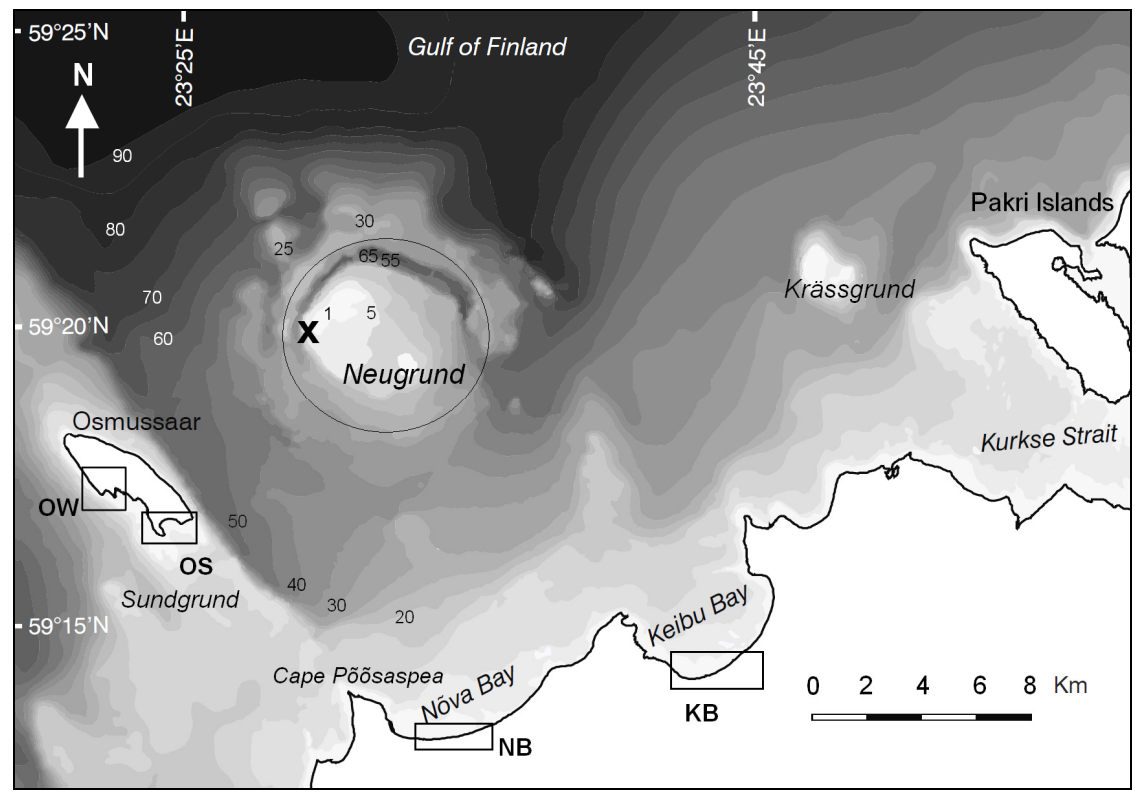

Figure 2: $\quad$ Map of the Neugrund structure with the crater rim marked by a circle [1]; the location of the RDCP mooring (X) and the coastal study sites at Osmussaar Island (OW, OS), Nõva (NB) and Keibu (KB) Bays. 


\subsection{The coasts of Osmussaar, Nõva-Keibu and Pakri}

The sandy beaches of Nõva and Keibu bays separate the limestone scarp and accumulative pebble-shingle shores that dominate Osmussaar Island in the west and Pakri Peninsula to the east (Figs. 2, 3) [5-7]. The study area is experiencing post-glacial land uplift with a current rate of $2.8 \mathrm{~mm} / \mathrm{yr}$ [8].

Osmussaar is a $5 \mathrm{~km}$ long relict island of the Baltic Clint, overlain by a thin layer of Quaternary deposits, which emerged from the Baltic Sea about 3000 years ago [7]. The highest elevation is approximately 8 meters above mean sea level. An Ordovician limestone cliff up to $6 \mathrm{~m}$ high is the most characteristic feature on the northern part of the Island, whereas accumulative gravel-pebble beach ridges $2-3$ meters high cover the southern part of the island $[5,7]$.

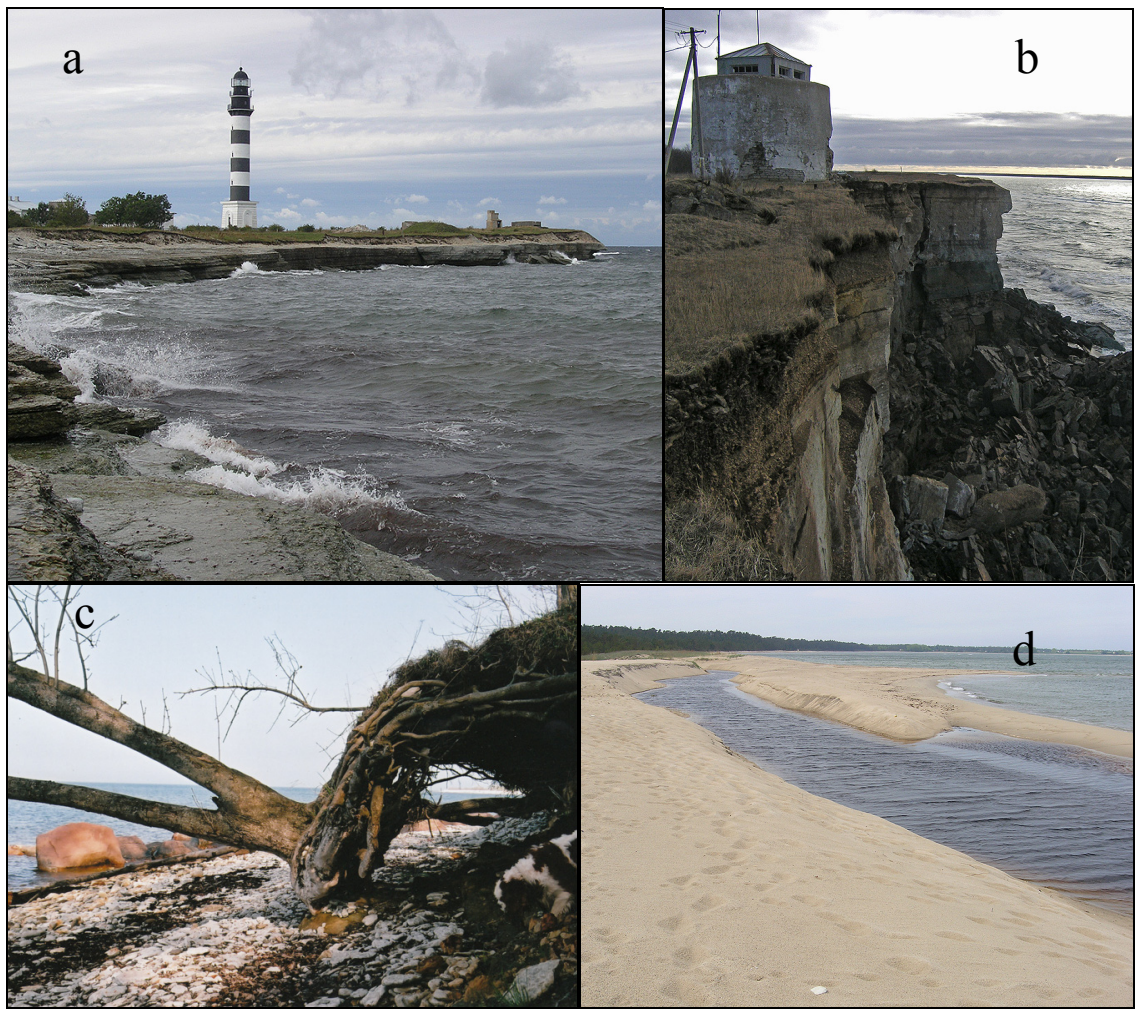

Figure 3: $\quad$ Northern coast of Osmussaar Island (a), the $20 \mathrm{~m}$ high limestone cliff at Pakri Peninsula (b), coastal destruction after the 2001 winter storm at Pakri Peninsula (c), and sandy coast at Keibu Bay (d). (Photos by H. Tõnisson and Ü. Suursaar.)

Increments of the spits often rejoin the main island and therefore several coastal lagoons or lakes can be found behind the spits.

The coastal sea is less than 2 meters deep above a $200-300 \mathrm{~m}$ wide limestone bench on the western side of the island. Further offshore, the depth increases 
rapidly. The main shore processes are erosion from the cliff, which recedes approximately $9 \mathrm{~cm} / \mathrm{yr}$, longshore southward transport of gravel-pebble and accumulation of material as beach ridges at the southern end of the island [9].

The Pakri Clint Peninsula is a plateau bounded by steep escarpments - the Baltic Clint. The elevation of the Pakri cliff attains ca. 25 meters, which decreases from north-west to south-east. Pakri cliff rose from the sea about 7000 years ago, upon which it has been subject to wave erosion [5,6]. Erosion of the cliff by wave activity and weathering is relatively slow. The abraded sediments are transported southward along the shore.

Keibu and Nõva Bays are located off the Estonian mainland, approximately 20-25 km west of Pakri Peninsula and 10-15 km south-east of Osmussaar (Fig. 2 ). The coastal sea in both bays is relatively shallow and coastal slope is very gentle. Ancient coastal formations and dunes are located at different heights landwards with older formations being farther from and higher than the contemporary shoreline. The present shores themselves are sandy with a grain size varying between $0.15-0.25 \mathrm{~mm}$. Glacial sediments are abraded from the sides of the peninsulas bordering the bays, and the material is transported towards the heads of the accumulative bays $[5,9]$.

\section{Material and methods}

\subsection{In situ measurements of waves and currents}

The hydrodynamic study is based on measurements of waves and currents using the Doppler-effect based current profiler (RDCP-600 by AADI Aanderaa) in the Neugrund Bank area of the Gulf of Finland $\left(59^{\circ} 19^{\prime} 47^{\prime \prime} \mathrm{N} ; 2^{\circ} 29^{\prime} 33^{\prime \prime} \mathrm{E}\right.$, Figs. 1, 2) between 20 November 2009-24 April 2010. The instrument was installed on the seabed at a depth of ca. $15 \mathrm{~m}$. Over 155 days the instrument recorded hourly data on currents at seven depth layers (without cell overlap), wave parameters, sea level variations and water column properties, such as water temperature, salinity and turbidity. The wave data included significant wave height (Hs), as well as maximum wave heights and wave periods.

\subsection{Meteorological data}

Meteorological data were obtained from the Pakri meteorological station $\left(59^{\circ}\right.$ $23^{\prime} 22^{\prime \prime} \mathrm{N} ; 24^{\circ} 02^{\prime} 24^{\prime \prime} \mathrm{E}$ ), located about $30 \mathrm{~km}$ east of the mooring site and operated by the Estonian Meteorological and Hydrological Institute (EMHI). The Pakri station has been operational since 1865, but the exact position of the station on the Pakri Peninsula has slightly changed, most recently in September 2003. Digitized wind records are available since 1966. Winds have been measured by "weathercocks" (wind vanes of Wild's design) during 1966-1976, automatic anemorhumbographs during 1976-2003, and MILOS-520 automatic weather stations since September 2003. 


\subsection{Wave hindcast}

In order to assess long-term variations in forcing conditions for the coasts encircling the Neugrund, a wave hindcast was performed using a semi-empirical SMB-type wave model. The SMB-model, also known as the significant wave method, is based on the fetch-dependent shallow-water equations by Sverdrup, Munk, and Bretschneider [10]. Based on wind data, the model calculates the significant wave height, wave period and wavelength for a chosen location. As the role of remotely generated waves (swell) is small and the memory time of the wave fields in the Baltic Sea is relatively short [11], this relatively simple method can deliver reasonably good and fast results for this study area $[3,4]$.
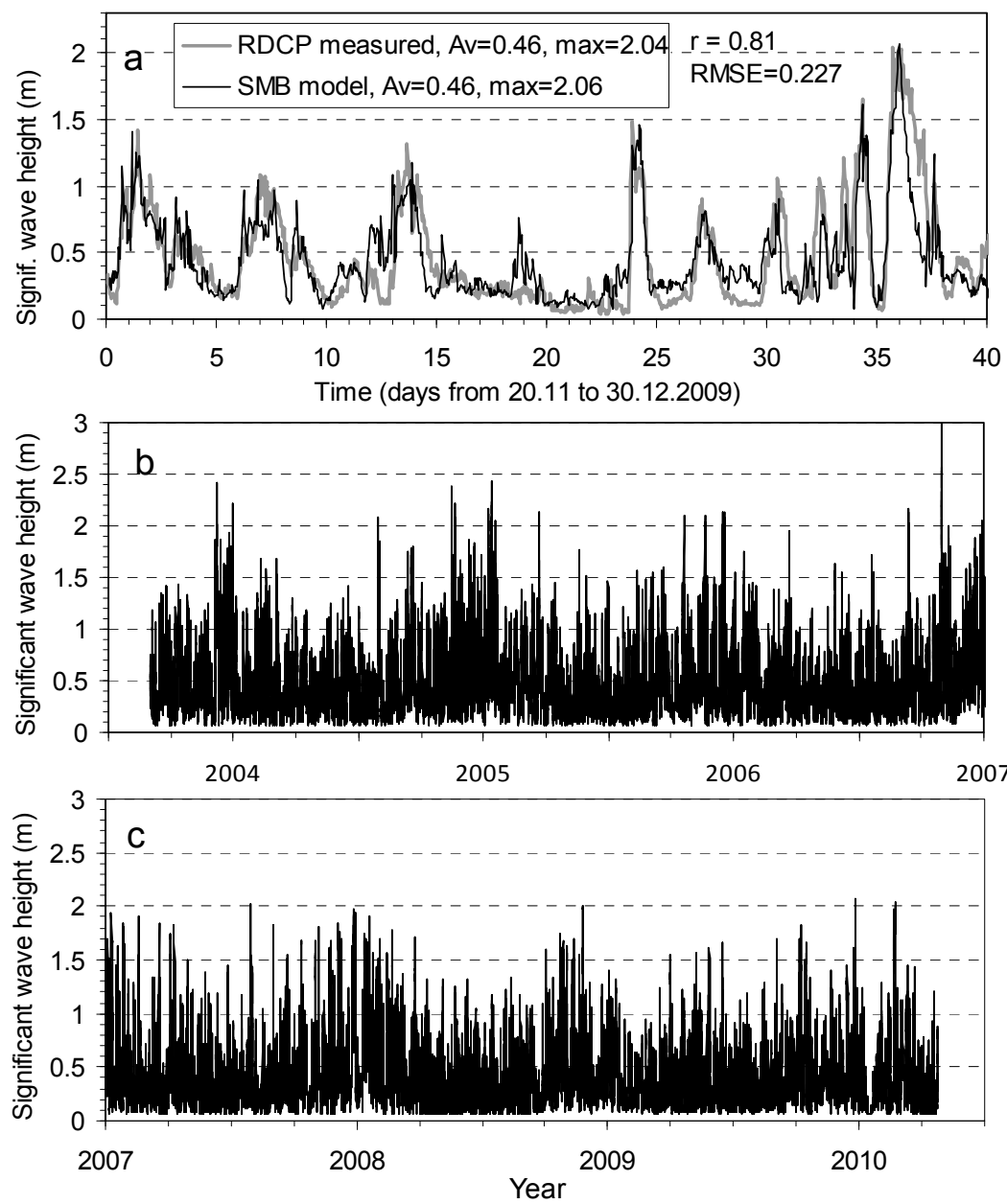

Figure 4: Wave measurements and the model calibration (a), wave hindcast at the Neugrund from September 2003 to April 2010 (b, c). 
Our earlier comparison of hindcasts between the SMB model and $3^{\text {rd }}$ generation WAM model [12] showed that SMB-type models can be used for site-specific long-term hindcasts when the gridded geostrophic wind data required for the $3^{\text {rd }}$ generation wave models are not available in the desired resolution or length.

In this study, the wind data from Pakri station were used to run the wave model, and the wave data obtained by the RDCP served to calibrate the model. The calibration was done by prescribing fetch distances for different wind directions with a step of $10^{\circ}$ and searching for appropriate depth parameter. The fetch is usually measured as the headwind distance from the nearest shore for that wind direction, and a procedure for taking into account basin properties in a wider wind sector is applied [13]. In our case, the calibration was done iteratively, in an attempt to keep the maximum and average wave heights equal in the modelled and reference series, to maximize the correlation coefficient and to minimize the RMS error. In fact, the procedure modified slightly the "real" geographical fetches in order to compensate for the wind speed impediment of certain wind directions at the Pakri station. For the hourly-based 40-day calibration period (Fig. 4a), we obtained a correlation coefficient 0.81 and an RMSE of $0.227 \mathrm{~m}$ (relative RMSE $=11 \%$ ). The site-dependently calibrated model was then used in multi-year wave hindcast at $1 \mathrm{~h}$ or $3 \mathrm{~h}$ interval, as it would have been measured by the same RDCP at the same location.

The calibration quality in this study was somewhat lower than in our previous efforts near Harilaid-Vilsandi $(\mathrm{r}=0.88, \mathrm{RMSE}=0.23 \mathrm{~m}, 7.4 \%)$ [3] and KundaLetipea $(\mathrm{r}=0.92, \mathrm{RMSE}=0.22 \mathrm{~m}, 7.8 \%)$ [4], due largely to the greater distance (about $30 \mathrm{~km}$ ) between the wind measurement site at Pakri and the wave hindcast site at Neugrund. The corresponding distances at Harilaid-Vilsandi and at Kunda-Letipea were only 7 and $10 \mathrm{~km}$, respectively. Calibration using Ristna wind data (90 km away) and Vilsandi station data (140 km away) yielded $\mathrm{r}=0.61$ and $\mathrm{r}=0.51$, respectively. In addition, the correlation was impaired by the rugged bottom topography at the Neugrund site. The modelling quality is lower also due to some islands (e.g. Osmussaar to SW) and shallow banks (to NE and SE), as the simple wind-wave fields may be occasionally "contaminated" by refraction, breaking and other shallow water effects [13].

\subsection{Coastal studies}

The dynamics of the seashores (Figs. 2, 3) were assessed by comparing areal changes in shore formations and changes in shoreline positions in space and time. Topographic maps in a 1:25 000 scale from 1947, 1961 and 1981, as well as orthophotos (from 1998, 2005 and 2008, pixel sizes between 25 and $100 \mathrm{~cm}$ ) were compared to analyze the geomorphology, changes in shoreline position and character of shore processes in the study sites. Topographic maps from 1900 (1:42 000), 1935 and $1939(1: 50$ 000) were used to analyse the general tendencies in shore development.

GPS-measurements were taken during 2004-2008 to ascertain short-term changes in shoreline position, contours of beach ridges and locations of their crests. The boundaries of different shore types were mapped using Garmin 12 
and Garmin 60CS GPS instruments, both of which are accurate to within $3 \mathrm{~m}$. Data acquired in the additional field surveys in 2004, 2005 and 2009 were used to determine sediment origin and its direction of transport. These data were processed using MapInfo software, which was also used to calculate reductions in the erosion areas and increases in accumulative areas (see [14] for more details).

\section{Results and discussion}

\subsection{Measured hydrodynamic conditions in 2009-2010}

As a result of meteorologically-induced sea level variations, the depth of the instrument varied between 13.9 and $15.2 \mathrm{~m}$ over the 155 days. The maximum wave height attained $3.1 \mathrm{~m}(\mathrm{Hs}=2.1 \mathrm{~m})$ on 20 February 2010 (Fig. 4a) with an sustained wind speed of $12.6 \mathrm{~m} / \mathrm{s}$. In fact, the average wind speed did not exceed $13.2 \mathrm{~m} / \mathrm{s}$ (with $21 \mathrm{~m} / \mathrm{s}$ gusts) throughout the measuring period. The average measured sub-surface $(1-3 \mathrm{~m})$ current speed module was $9.8 \mathrm{~cm} / \mathrm{s}$, and the maximum attained $36 \mathrm{~cm} / \mathrm{s}$ in this location. Ordinary waves and sea level variations during occasional (up to 2-3 m) storm surges (e.g. in 1967, 2001, 2005) are evidently the main hydrodynamic factors for the coastal changes in the almost tideless Estonian coastal sea $[14,15]$. The site was covered by ice during 40 days in February and March - a rare event in the mild winters of the last decades [16]. The water temperature varied between -0.2 and $8^{\circ} \mathrm{C}$, and salinity between 5.9 and 7.2. Variations in near-bottom water turbidity were influenced by wave generated resuspension from nearby shoals.

\subsection{Hindcast wave conditions during 2003-2010}

The maximum wave height (Hs) during the most reliable hindcast period from September 2003 to April 2010 attained $3.2 \mathrm{~m}$ (Fig. 4). Wave statistics suggest the maximum wave height would have been about $5 \mathrm{~m}$. Owing to the rugged bottom topography and fetch limitations, the waves at the Neugrund Bank are not particularly high compared to our previous study sites [3, 4]. Both the average wave heights and higher percentiles showed clear seasonal variations (Fig. 5a) confirming that rough seas in the Baltic Sea prevail in autumn and winter, and calm conditions are more likely in spring and summer. The overall decreasing trends (Fig. 5a) are similar to those at Harilaid and Letipea for the same period [4]. However, it is impossible to extrapolate changes in wave conditions for longer periods. Although the hindcast was constructed for the entire period covered by the digitized wind data at the Pakri station (Fig. 5b), both the unnatural structure of the series as well as information about the exact changes in the location of the Pakri station indicate to significant inhomogeneity. As the model calibration is based only for the present location of the wind instrument, the periods 1966-1992 and 1993-2003 should be considered questionable. However, lying geographically between Harilaid and Kunda, the coastal developments can be viewed on the basis of these results (Fig. 5c). 

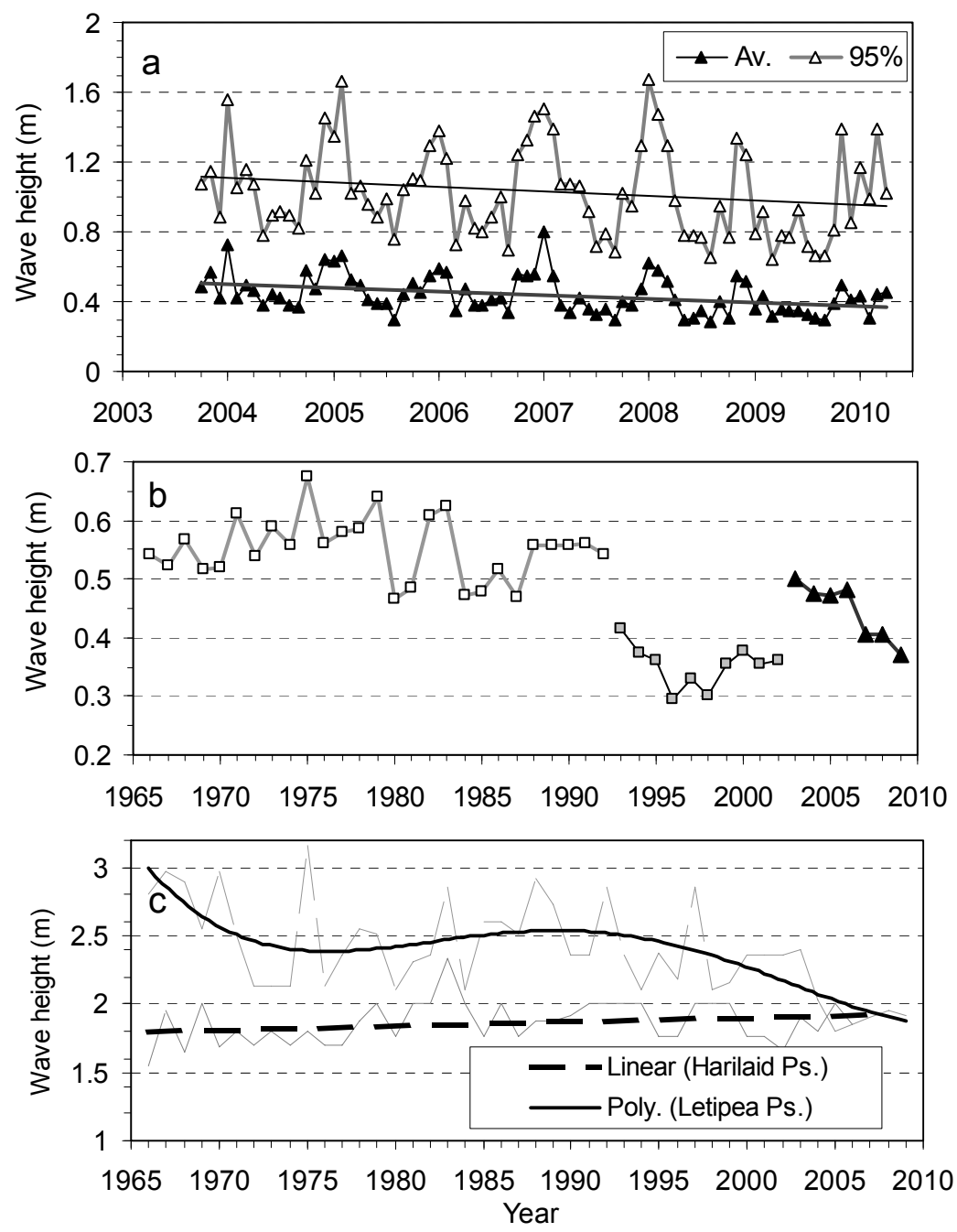

Figure 5: Average and 95\% wave heights (in terms of Hs) computed on monthly basis from September 2003 to April 2010 (a); averages of annual wave hindcast data (1966-2010) (b); different markings refer to inhomogeneity in wind forcing data series. Long-term tendencies in high wave events (99-percentiles) according to data obtained at Harilaid [3] and Letipea [4] (c).

\subsection{Coastal developments in relation to long-term changes in wave climate}

The Osmussaar scarp (Fig. 3a) is slowly retreating $(9 \mathrm{~cm} / \mathrm{yr})$ on the northern and eastern coast of the island, whereas the coastline is migrating seaward in the south-west and southern part as a result of formation of accumulative beach ridges and spits (Figs. 6, 7). 


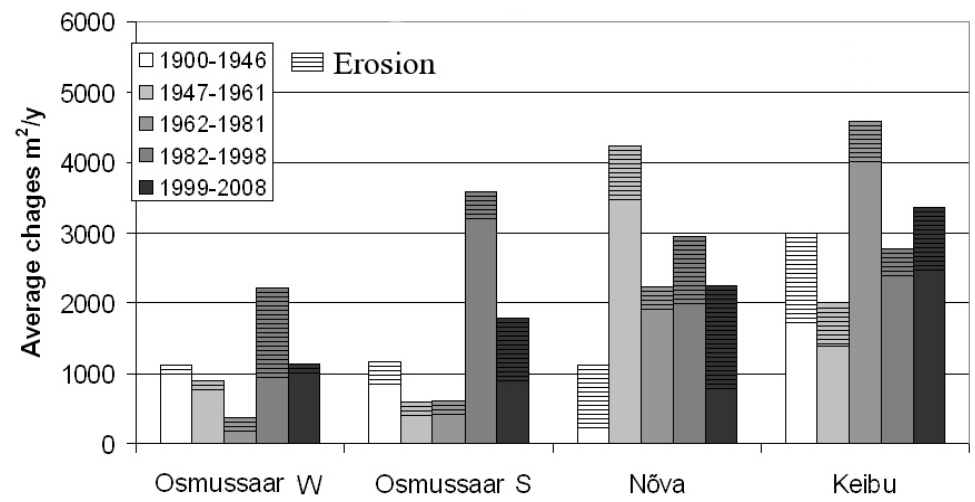

Figure 6: Average areal changes in the study sites during different time periods. Horizontal stripes (top part of the bar) indicate the share of erosion.

The spit in the southern part of the island has grown nearly $800 \mathrm{~m}$ southeastward in the last century (Fig. 7). The former small bay in the southern part of the island became a lake when another spit-like formation closed the entrance into the bay between 1900 and 1935. In addition, the southern coast of the island has migrated over 120 meters southward towards the small bay. The most rapid
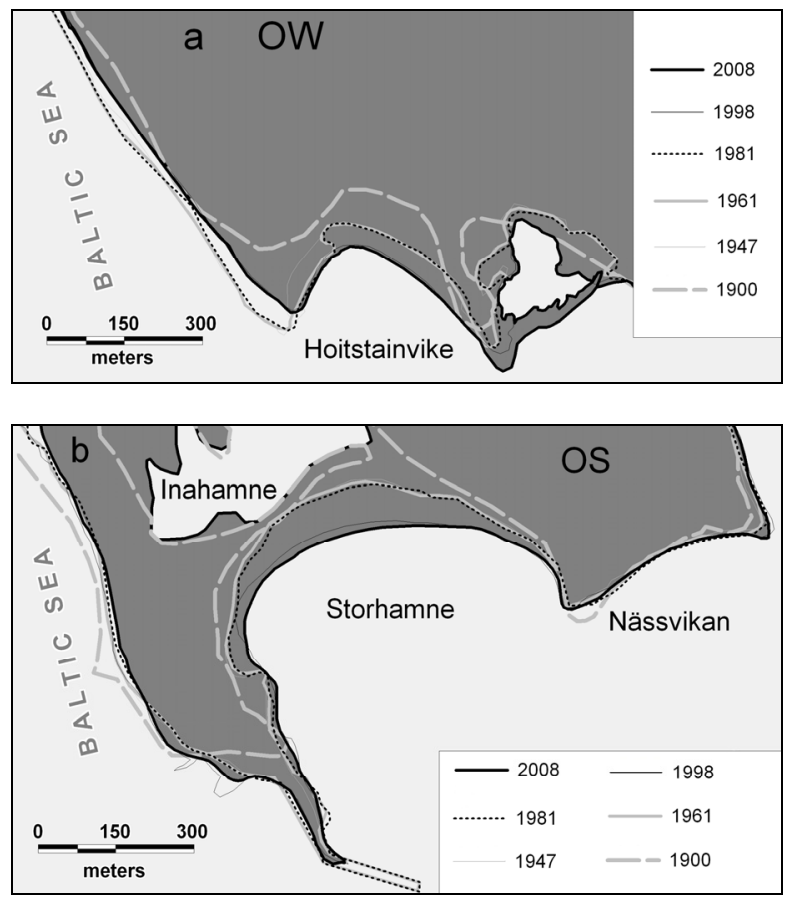

Figure 7: Changes in coastal position at Osmussaar OW and OS study sites. 
changes in Osmussaar have occurred either during exceptionally strong storms or in periods of increased cyclonic and wave activity, the last high phase of which occurred in 1980s-1990s (Fig. 5) [3, 15]. Map analyses indicate that the processes were twice as rapid during 1982-1998 than in other periods (Figs. 6, 7). Erosion in the proximal part of the spit or former transport zone has increased rapidly since the beginning of the 1980s. Similar tendencies have been observed in the west Estonian study sites [14].

Nõva Bay (Fig. 3d) is a good example of the impact of the increased storminess on the sandy beaches. The most rapid changes in Nõva beaches occurred during 1947-1961 (Fig. 6). The rate of the shore processes has decreased slightly but the degree of erosion has increased significantly since this period. Erosion has even exceeded accumulation during the last decade. Therefore, we can conclude that formerly accumulative sandy shore at the head of the Nõva Bay has started to retread as a result of increased storminess.

Keibu Bay is the least exposed study site and therefore the impact of the increased west-storms is not clearly evident. The rate of the shore processes in Keibu Bay was the most rapid during 1962-1981 (Fig. 6). However, the share of erosion never exceeded a third of the total changes during the analysed periods. Due to sea level rise and increased storminess [11, 14, 15], very few sandy beaches in the world are still accumulative, and we can conclude that exposure to the prevailing storm winds allows the sandy shores in Keibu Bay to belong among those few accumulation dominated shores.

\section{Conclusions}

Based on hydrodynamic measurements and the semi-empirical wave hindcast at the Neugrund submarine impact structure, it was found that the main hydrodynamic forces acting on seashores in the studied locations are waves and occasional strong storm surges, which may elevate the sea level up to 2-3 m above the mean sea level. Owing to rugged bottom topography of the Neugrund bank, the wave conditions are rather site dependent. The coastal processes on the westerly exposed coasts of Osmussaar are continuously active, whereas in the northerly exposed coastal sections and Keibu Bay accumulation prevails as wave activity is declining. The shores in Nõva Bay have been accumulative until the last decade, but subsequent storms have caused them to retreat. Although the Osmussaar scarp is slowly retreating on the north-western and northern side of the island, the coastline is migrating seaward in the south as a result of the formation of accumulative beach ridges and spits. The most rapid changes have occurred either during strong storms or in periods of increased cyclonic and wave activity, the last high phase of which occurred in 1980s-1990s.

\section{Acknowledgements}

The study was supported by Estonian Science Foundation grants No.7609 and 7564, as well as by target financed themes SF0180104s08 and SF0280009s07. 


\section{References}

[1] Suuroja, K. \& Suuroja, S., Neugrund structure - a submarine meteorite crater at the entrance to the Gulf of Finland. Estonia Maritima, 4, pp. 161$189,1999$.

[2] Suuroja, K. \& Suuroja, S., Neugrund structure - the newly discovered submarine early Cambrian impact crater. Lecture Notes in Earth Sciences, 91, pp. 389-416, 2000.

[3] Suursaar, Ü. \& Kullas, T., Decadal variations in wave heights off Cape Kelba, Saaremaa Island, and their relationships with changes in wind climate. Oceanologia, 51, pp. 39-61, 2009.

[4] Suursaar, Ü., Waves, currents and sea level variations along the Letipea Sillamäe coastal section of the southern Gulf of Finland. Oceanologia, 52 pp. 391-416, 2010.

[5] Orviku, K., Estonian seacoasts. Valgus: Tallinn, 112 pp., 1974.

[6] Kink, H. \& Miidel A., (Eds.). The Pakri Peninsula - Nature and Human Activity. Estonian Academy Publishers: Tallinn, 94 pp., 1996.

[7] Mäesalu, M., Landscape structure and development of Osmussaar Island. Bachelor thesis in Tallinn Pedagogical University. 63 pp., 2005. [manuscript in Estonian with English summary].

[8] Vallner, L., Sildvee, H. \& Torim, A., Recent crustal movements in Estonia. J. Geodyn., 9, pp. 215-223, 1988.

[9] Orviku, K., Some aspects of shallow water sedimentation along the Estonian coast. The Baltic Sea, ed. B. Winterhalter, Geological Survey of Finland: Special paper, 6, pp. 73-77, 1988.

[10] Seymour, R.J., Estimating wave generation in restricted fetches. J. ASME WW2, May 1977, pp. 251-263, 1977.

[11] Soomere, T., Myrberg, K., Leppäranta, M. \& Nekrasov, A., The progress in knowledge of physical oceanography of the Gulf of Finland: a review for 1997-2007. Oceanologia, 50, pp. 287-362, 2008.

[12] Räämet, A., Suursaar, Ü., Kullas, T. \& Soomere, T., Reconsidering uncertainties of wave conditions in the coastal areas of the northern Baltic Sea. Journal of Coastal Research, SI 56, pp. 257-261, 2009.

[13] Massel, S.R., Surface waves in deep and shallow waters. Oceanologia, 52, pp. 5-52, 2010.

[14] Tõnisson, H., Orviku, K., Jaagus, J., Suursaar, Ü., Kont, A. \& Rivis, R., Coastal Damages on Saaremaa Island, Estonia, Caused by the Extreme Storm and Flooding on January 9, 2005. Journal of Coastal Research, 24, pp. 602-614, 2008.

[15] Suursaar, Ü., Kullas, T. \& Szava-Kovats, R., Wind- and wave storms, storm surges and sea level rise along the Estonian coast of the Baltic Sea. Ravage of the Planet II. Book Series: WIT Transactions on Ecology and Environment, 127, WIT Press: Southampton, Boston: pp. 149-160, 2010.

[16] Sooäär, J. \& Jaagus, J., Long-term variability and changes in the sea ice regime in the Baltic Sea near the Estonian coast. Proc. Estonian Acad. Sci. Eng., 13, pp. 189-200, 2007. 